\title{
Forum
}

\section{Interview with Yvonne Ridley}

\author{
Wendy O'Shea-Meddour
}

\begin{abstract}
The story of British freelance journalist and author Yvonne Ridley is fascinating. Ridley, an experienced and well-respected journalist, was the chief reporter for The Sunday Express and had worked for several newspapers, including The Sunday Times, The Independent, and The Observer. But in September 2001 she became a household name when captured by the Taliban in Afghanistan. On her release, she famously told the awaiting press that her captors had treated her with "courtesy and respect." This was not the expected response, and Fleet Street subsequently vilified her.
\end{abstract}

Her decision to honor a promise made to an imam while in Afghanistan led her to study and, to her own surprise, embrace Islam in June 2003. This did little to improve her popularity with the press. Calling upon the resilience and determination that had made her such a good journalist, she moved from London to Qatar to take up a position as senior editor at al-Jazeera's soonto-be-launched English website. After just 5 months, and under rather mysterious circumstances, she was sacked. This prompted Ridley to write her first novel Ticket to Paradise. Ridley has since returned to England and is now a prominent Muslim activist and anti-war campaigner.

\footnotetext{
Wendy O'Shea-Meddour is a British Academy postdoctoral research fellow at Oxford University and teaches critical theory in the Department of English Literature. She gained AHRB (Arts and Humanities Research Board) Awards for her M.A. and Ph.D. in critical and cultural theory at Cardiff University, and is currently writing a book about the representation of Muslims in contemporary literature. She has published in several journals, including Textual Practice and French Cultural Studies. Her main interests include postcolonial theory, deconstruction, feminist theory, contemporary fiction, and Islam.
} 
O'ShEA-Meddour: What was the hardest thing about becoming a Muslim? RIDLEY: Like many converts, I had great difficulty in explaining the conversion to my Christian parents, so much so I informed my mother by email. Giving up alcohol was easy and no great sacrifice because my health improved immediately and I discovered a new found confidence and inner peace. I am still wrestling over wearing the hijab because, although it is an obligation in Islam, I am not ready to take that step yet. And my final "jihad" is with my cigarette habit, which I am sure I will conquer in the near future.

O'Shea-Meddour: Although Islam is often considered to be a conservative religion, according to Jeffrey Lang (another famous western Muslim), most western converts are "non-conformists." In your various capacities (i.e., as a journalist, mother, and activist), is this how you would describe yourself? RIDLEY: I have always questioned authority but I think that is part and parcel of being a responsible journalist. I've always tried to be an individual and have been reluctant to follow the crowd ... apart from football when I've been quite happy to be a Newcastle United supporter through thick and thin. As a journalist I never followed the pack. When I went to Pakistan in September 2001 to cover the build up to war, I deliberately checked into a hotel away from British journalists. I prefer to work on my own and develop my own stories.

As a mother, it's hard to be objective when trying to judge myself. When Daisy arrived she didn't come with a manual or trouble-shooting book, but I know I have the unconditional love of my daughter and that is a terrific feeling. She says I'm the best mum in the world and that's the only opinion that counts as far as I am concerned. As a woman I've always been a promoter of women's rights and equality but I never realized how uneven the playing field was until I had my daughter. To compete with men on equal terms in western society many women have sacrificed motherhood for their careers and that is a shame. Until we are allowed to compete as women and potential mothers we will never have true equality.

As to the first part of the question, I don't think Islam is conservative, but it hasn't changed one dot or squiggle in 1400 years and, thankfully, has never diluted the content of the Qur'an to court popularity. I think this is where other religions have gone wrong and now they're in serious trouble. The Christians are ripping themselves apart over homosexual issues because some sections want to modernize - as they call it. If they return to their roots, Christians would find quite a different kind of faith and practice to the one that they follow today. 
O'Shea-Meddour: Many now refer to you as a "Muslim activist." Is this a label with which you identify? If so, what do you perceive your role to be? RIDLEY: I am a Muslim and I am an activist, and sometimes the two cross over but are always compatible. If I see an injustice, I shout long and hard and hope someone will sit up and take notice. This can be an individual wronged, or the injustice that is Palestine, or the immoral and illegal war in Iraq.

O'ShEA-Meddour: Some say that the torch of Islam will pass to western Muslims as they learn their new faith from the source rather than from local traditions. Do you agree with this, or do you think that innovations might be introduced this way?

RIDLEY: There are Muslims in the West who do act as trail blazers. But quite often, these are Muslims who have been reinvigorated in their faith, sort of born again as well as reverts who've come to Islam from another faith or none at all.

O'SheA-MEDDour: How do you see the future of Islam in Britain?

RIDLEY: I think there are exciting times ahead for Muslims in Britain, if they are prepared to rise to the challenge and stand up for their beliefs. Many Muslims come from a background of oppression and intimidation, so it will take time for them to have the confidence to emerge and stand up for their beliefs. I think the faith will grow stronger, despite possible troubled times ahead for the Muslims. As has been said before, holding on to your din [religion] is going to be like holding on to burning coals.

O'SheA-MedDour: It is well known that you made significant improvements while working for al-Jazeera, and that your colleagues protested against the decision to sack you. Why do you think you were asked to leave? RIDLEY: Part of it lies in my previous answer. The Arab and Gulf states are ruled oppressively. Sometimes it is overt and other times it is more subliminal. I think I was seen as a threat by a few individuals who felt unable to challenge me face-to-face. Perhaps I reminded them of their own craven behavior towards power and authority. A letter sent to my lawyers said I was "a threat to national security," but we are still trying to establish whose security. I was certainly bringing in stories which exposed and embarrassed the inhumane behaviour of the US military in Afghanistan and Iraq. I actively encouraged and empowered the staff to initiate their own stories instead of cutting and copying wire stories from Reuters and AP. 
O'ShEA-Meddour: Do you think that it is a good or a bad thing that photographs showing the torture of Iraqis by U S and British Military forces have been so heavily publicized?

RIDLEY: This sort of behavior in any society should be exposed; hence, the front pages and headlines around the world ... although it took the US media some time to catch up with everyone else. Sadly, this sort of behavior is also happening in US and UK prisons, not to mention Guantanamo Bay and most prisons and institutes in the Arab world. So there is a little bit of hypocrisy in the outrage displayed in the Arab world, where human rights abuses are all too common.

O'ShEA-Meddour: What prompted you to write your novel Ticket to Paradise? Did you enjoy your foray into fiction?

RIDLEY: Ticket to Paradise was inspired by a real situation that came my way when I was offered the chance to interview a potential suicide bomber. I was confronted with all sorts of moral dilemmas and, in the end, did not do the interview. I thought about it often, and the character in my book made the decision to go ahead - with devastating consequences. I thoroughly enjoyed writing the book. It was a bit of a release.

O'SheA-MedDour: Would you like to work for a mainstream British newspaper again? If so, in what capacity?

RIDLEY: I love writing and would love to work in a Robert Fisk or John Pilger-style capacity. I would also love the challenge of a column in mainstream media. I already have one in Muslims Weekly in New York.

O'Shea-MedDour: Please forgive this question, but how would you answer the accusation that you exploited your capture by the Taliban financially and converted to Islam as some sort of a publicity stunt?

RIDLEY: Financially, I have never been worse off. I walked out on a £50ka-year job with superb expenses and the champagne lifestyle that went with it. Far from exploiting the situation, I had to reinvent myself because I could no longer work as an undercover journalist as a result of the global publicity my capture attracted. Investigative work was my speciality, but now I concentrate on humanitarian reporting.

If converting to Islam was a publicity stunt it was a costly one, because my work tailed off. Islam is a complete way of life, not just a faith, and it is a huge commitment to give for a publicity stunt. I have given a lifetime commitment by taking the shahadah, and I am very proud of my faith. 
Cynics will always try and denegrade people's actions, but I know what I have done and why, and, more importantly, Allah knows my intentions.

O'Shea-Meddour: In many of the interviews that you have given, it is clear that the interviewer (often male and rather old-fashioned) is not only puzzled but also angered and upset by your belief in the Qur'an. Although I suspect that your knowledge of the western feminist tradition is greater than their's, "concern" generally centers on your supposed abandonment of your woman's rights. Have you been surprised by the hostility that you sometimes face? What do you think is its cause?

RIDLEY: The root cause of the hostility is the veil of ignorance and bigotry worn by those who fear Islam. One of my most satisfying interviews was with a radio presenter who kept goading me about becoming a Muslim, because, in his view, I had sold out as a promoter of women's rights. I remember him almost cowering behind his mike, looking like a frightened rabbit trapped by headlights when I raised my voice and said: "Do I look or sound like an oppressed, subjugated woman or a woman that would allow a man to intimidate her?" Almost shaking, he stammered "No." Enough said. Funnily enough, chauvinistic colleagues give me much more respect, albeit subconsiously, than they did before. They no longer touch me, invade my space, or tell vulgar jokes or make lewd comments about others in my company.

O'Shea-Meddour: As non-Muslims repeatedly demand that you justify and explain your decision to become a Muslim, do you ever tire of being on the defensive or feel that, as a new Muslim in such a public space, you have taken on more than you can chew?

RIDLEY: I never tire of talking about my conversion, although I don't go around telling people unless they ask. And, I am not in the business of converting. I correct people immediately that I am not a scholar, nor ever likely to be, but I am happy to talk about my personal experiences.

O'ShEa-Meddour: Some British women feel that the mosque alienates them in the sense that they do not feel welcome or catered to. What is your experience of this?

RIDLEY: It is absolutely true, and when I gain in confidence - and have the time - it is an issue I want to address. I feel highly irritated when I am told I can't go into a mosque, and I just wish I had the guts, confidence, and Islamic knowledge to argue my case in an authorative, but calm, way. 
O'SHEA-MEDdOUR: How do you maintain and strengthen your faith? RIDLEY: My biggest source of inspiration are the sisters I meet. And when I address meetings and meet other women, it's as though they recharge my batteries.

O'ShEA-Meddour: In what ways do you feel that your past has prepared you for your new public role? (I'm thinking, hard-nosed, worldly journalist who can answer tough questions without loosing her cool!!)

RIDLEY: It is not Islamic to lose your cool and, thanks to that new inner peace, I feel I am stronger than ever. Words don't bother me. They are the tools of my trade, and I know how cheap they can be in the wrong hands. I'm not sure if it is in my genes, but the harder someone kicks the tougher I get. Yet a kind word from the right person can reduce me to tears.

O'SHEA-MEDdour: What are your plans for the future?

RIDLEY: I have now entered into British politics as a member of the RESPECT party, which was born out of the anti-war movement. I am a candidate in the European elections, which will take place on June 10, 2004, and I really feel I can win a seat. If I become a Euro MP, I will do my utmost to represent people in need, regardless of whether they are Muslims or not. I have no ambitions to become an establishment figure, so I think I might be quite fearless and not allow others to intimidate me, which could be great fun. In the distant future, I see myself living in a Muslim country where I can hear the azan (call to prayers). I'm not sure where, but I have a burning desire to learn Arabic and immerse myself in a pure Islamic way of life, pretty much the same way city slickers head for mountains and islands to seak peace and tranquility. 